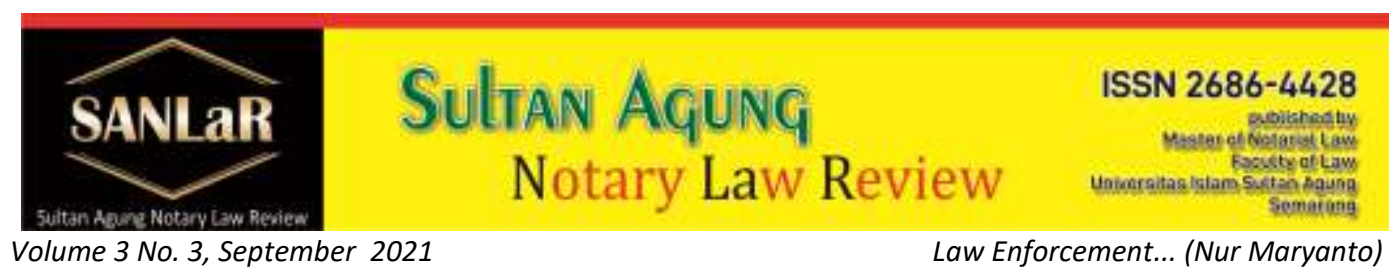

\title{
Law Enforcement Analysis against Notaries Who Do Negligence in Depositing Minutes of Deed
}

\author{
Nur Maryanto*) \\ ${ }^{*}$ Faculty of Law, Universitas Islam Sultan Agung (UNISSULA) Semarang, E-mail: \\ nurmaryanto2021@gmail.com
}

\begin{abstract}
The purpose of this study is to analyze: 1). Law enforcement against a notary who is negligent in keeping the minutes of deed in Pemalang Regency. 2) Obstacles and solutions in enforcing the law against a notary who neglects to keep the minutes of deed in Pemalang Regency. The approach method in this research is empirical juridical with the help of primary data or empirical data as the main data. The data used are primary and secondary data obtained through interviews and literature study, data analysis was carried out by analytical descriptive. The results of the research concluded: 1). Law enforcement against a notary who neglects to keep the minutes of deed in Pemalang Regency, namely starting with the submission of a report, summons and examination by the MPD, as well as the conduct of a trial by the MPW. Sanctions against a Notary who is proven to have violated the provisions of Article 16 paragraph (1) letter $b$, as regulated in Article 85, the sanctions are in the form of verbal warning, written warning, temporary dismissal, honorable discharge and dishonorable dismissal. The toughest sanctions imposed on notaries who violate the code of ethics and the Law on Notary Positions.
\end{abstract}

Keywords: Law; Enforcement; Sanctions; Negligence; Depositing.

\section{Introduction}

A notary is the only public official who has the right to make an authentic deed as a perfect means of proof. Notary is an extension of the State where he fulfills some of the duties of the State, especially in the field of civil law as stated in the 1945 Constitution of the Republic of Indonesia, that the State of the Republic of Indonesia is a State of Law. ${ }^{1}$ Notaries must be positioned as public officials who carry out duties. In the Regulation of Notary Positions (PJN) 1860 it is emphasized that the work of a Notary is an official job (ambtelijke verrichtingen)

\footnotetext{
1 Pengurus Pusat Ikatan Notaris Indonesia, Editor Anke Dwi Saputra, 2008, Jati Diri Notaris Indonesia Dulu, Sekarang Dan Dimasa Yang Akan Datang, Gramedia, Jakarta, p.34.
} 
and the only public official authorized to make authentic deeds, as long as there are no regulations that give similar authority to other officials. ${ }^{2}$ Then the Regulation of the Position of Notary above has been amended by Article 1 Paragraph 1 of Act No. 2 of 2014 concerning the Position of Notary which states that a Notary is a public official authorized to make authentic deeds and other authorities as referred to in this Law or based on this Law. ${ }^{3}$

Notaries are required to keep the minutes of deed stated in Article 16 paragraph (1) letter $b$ of the Law on Notary Positions which states that one of the obligations of a notary is to "make a deed in the form of a minutes of deed and save it as part of the Notary-protocol". "Minuta deed is the original deed that includes the signatures of the appearers, witnesses, and notaries. Minutes of deed, registers and supporting documents for making this deed are kept as part of the notary protocol". Stated in the Notary Position Act ${ }^{4}$. According to Afipuddin, the author concludes that one of the State Archives is in the vital category, including the Notary Protocol. Act No. 43 of 2009 which is a special rule (lex specialist) that regulates archives which should stipulate that the Notary Protocol is a State Archive with the obligation to be kept and maintained by a notary. ${ }^{5}$ According to Habib Adjie, what the author concludes is that in order to maintain juridical age, the deed is stored in its position as one of the complete parts of the Notary-Protocol, as perfect evidence for the parties contained in the deed and their heirs regarding everything contained in the deed, and in the form of a copy for the parties concerned. ${ }^{6}$

In legal construction, one form of state service is in civil law to the people in order to ensure legal certainty, namely facilitating the provision of evidence or related legal documents attributable to public officials in this case by a notary and the minutes of the deed on the deed become the state archives that must be saved. By carrying out such a batan, the notary is attributable to the state with the symbol of the state, namely the Garuda Bird. ${ }^{7}$

When the minutes of the Notary's deed are lost or damaged, due to the negligence of the Notary which results in losses for the party who has the

\footnotetext{
${ }^{2}$ C.S.T Kansil, et. al., 2003, Pokok-Pokok Etika Profesi Hukum, Pradnya Paramita, Jakarta, p.87.

${ }^{3}$ Karya Gemilang, 2009, Himpunan Peraturan Perundang-Undangan Jabatan Notaris dan PPAT, Indonesia Legal Center Publising, Jakarta, p. 2.

${ }^{4}$ R. SoegondoNotodisoerjo, 1993, Hukum Notariat di Indonesia, RajaGrafindo Persada, Jakarta, p. 176.

5 Afipuddin, Implikasi Hukum Protokol Notaris Sebagai Arsip Negara, Tesis Program Studi Magister Kenotariatan, Universitas Narotama, p.7

${ }^{6}$ Habib Adjie, 2009, Sanksi Perdata dan Administratif Terhadap Notaris Sebagai Pejabat Publik, Refika Aditama, Bandung, p.45

${ }^{7}$ Astari Pryandini, "Kedudukan Hukum Salinan Akta Notaris Dalam Hal Terjadinya Musnahnya Akta", Justitia Jurnal Hukum, Vol. 2 No.1, April 2018. 69.
} 
interest in the minutes of the deed, it can be said that the Notary has heeded the obligations imposed by UUJN-P, namely keeping the minutes of the deed, ensuring that the minutes of the deed must exist. Minutes of deed have the nature that they must be made one and once for legal actions, so there will be no legal action that has two minutes of deed. This explanation gives the crucial meaning of a minutes of deed, namely as the only evidence that what is stated in the deed is true with all its descriptions. ${ }^{8}$

The UUJN stipulates that when a Notary in carrying out his duties is proven to have committed a violation, the Notary may be subject to or sanctioned, in the form of a warning and dismissal either temporarily, with respect, and with disrespect. ${ }^{9}$ Pemalang Regency today has a high level of need for Notaries, because its people are starting to realize the importance of legal registration. This increase is in line with the importance of keeping the minutes of deed by the Notary.

Based on the background of the problem above, the writer is interested in analyzing the thesis problem about waqf with the title"Analysis of Law Enforcement Against Notaries Who Do Negligence in Depositing Minutes of Deed in Pemalang Regency". This study tries to answer the implementation of law enforcement against notaries who neglect to keep the minutes of deed in Pemalang Regency as well as obstacles and solutions in enforcing the law against notaries who neglect the storage of minutes of deeds in Pemalang Regency.

The approach method used in this study is an empirical juridical approach with the help of primary data or empirical data as the main data. Primary and secondary data sources obtained by interview method and literature review (study document). The data that has been collected both from field research and library research were analyzed using descriptive analysis methods.

\section{Results and Discussion}

\subsection{Law Enforcement Against Notaries Who Do Negligence Against Minuta Deed Deposits in Pemalang Regency}

Based on Article 2 of the Law on Notary Positions, a Notary is appointed and dismissed by the Minister. The Minister referred to in the appointment of a Notary is the Minister of Law and Human Rights. With the appointment of a Notary by the Minister of Law and Human Rights, a Notary can carry out his

\footnotetext{
8 Ibid.

${ }^{9}$ Sri yuniati dan Sri Endah Wahyuningsih, Mekanisme Pemberian SanksiTerhadap Notaris Yang Melakukan Pelanggaran Kode Etik Jabatan Notaris, jurnal akta, vol. 4, no.4, 4 December 2017, p. 588-589
} 
duties freely without being influenced by the executive body and other legal entities. The meaning of freedom here is so that the Notary can carry out his position later to be able to act neutrally and independently. In addition, in carrying out his duties, a Notary must have responsibilities, namely: ${ }^{10}$

a. Notaries are required to make the deed properly and correctly. That is, the deed that was made contained the legal will and the request of the interested party because of his position.

b. Notaries are required to produce a quality deed. That is, the deed made is in accordance with the rule of law and the will of the interested party in the true sense. The notary must explain to interested parties the truth of the contents and procedures of the deed he made.

c. Positive impact. This means that anyone will admit that the contents of the notary deed have perfect evidence.

In making an authentic deed, the Notary has an obligation to make a deed in the form of Minutes of Deed. According to Article 1 number 8 of the Law on Notary Positions, the Minutes of Deed are the original deed that include the signatures of the appearers, witnesses and the Notary, which is kept as part of the Notary Protocol. Notary Protocol is a collection of documents which are state archives that must be stored and maintained by a Notary in accordance with the provisions of laws and regulations. The minutes of this deed must be kept by the Notary, given the month number and entered in the notary deed register book (repertorium) and given the repertorium number. ${ }^{11}$

In Article 16 point 1 letter b of the Law on Notary Positions it is explained that the obligation to keep the minutes of deed as part of the Notary Protocol is intended to maintain the authenticity of a deed by keeping the deed in its original form, so that if there is a forgery or misuse of grosse, a copy, or a quote thereof can immediately known easily by matching it with the original. Based on the provisions of the Law on Notary Positions ${ }^{12}$, it can be seen that the Notary Keeping Protocols needs to act carefully in storing every protocol submitted to him, for example by storing in a safe place and free from the dangers of theft, fire hazards, humid temperatures, and animal hazards. -animals that can damage

\footnotetext{
10 Maya Malinda Panjaitan, Analisis Yuridis Tanggung Jawab Notaris dalam Membuat dan Menyimpan Minuta Akta, Premise Law Journal, Volume XIV 2017, p.7

${ }^{11}$ Cut Era Fitriyanik, The Responsibility of Notary Towards Keeping The Minutes of Legal Documentary as a Part of Notary Protocol, Kanun Jurnal IImu Hukum, Nomor 58 XIV December, p. 395

12 A Chuasanga, Ong Argo Victoria. (2019). Legal Principles Under Criminal Law in Indonesia and Thailand, Jurnal Daulat Hukum, Vol 2, No 1 (2019) http://jurnal.unissula.ac.id/index.php/RH/article/view/4218 see Deen, Thaufiq., Ong Argo Victoria \& Sumain. (2018). Public Notary Services In Malaysia. JURNAL AKTA: Vol. 5, No. 4, 1017-1026. Retrieved from http://jurnal.unissula.ac.id/index.php/akta/article/view/4135
} 
the deed, so that the document is not lost, damaged and destroyed. ${ }^{13}$ So that the Notary is not negligent in his obligations, the Notary needs to be supervised by the Regional Supervisory Council (MPD), Regional Supervisory Council (MPW) and the Central Supervisory Council (MPP) so that if there is negligence in keeping the minutes of deed or violations of the protocol, law enforcement can immediately be carried out. The mechanisms or procedures for reporting are: ${ }^{14}$

\section{Report Submission}

a. Reports can be submitted by parties who feel aggrieved.

b. Reports must be submitted in writing in the Indonesian language accompanied by accountable evidence.

c. Reports regarding alleged violations of the Notary Code of Ethics or violations of the implementation of the Notary's position are submitted to the Regional Supervisory Council.

d. Public reports other than those referred to in paragraph (3) shall be submitted to the Regional Supervisory Council.

e. In the event that the report as referred to in paragraph (3) is submitted to the Regional Supervisory Council, the Regional Supervisory Council will forward it to the competent Regional Supervisory Council.

f. In the event that the report as referred to in paragraph (3) is submitted to the Central Supervisory Council, the Central Supervisory Council shall forward it to the competent Regional Supervisory Council.

2. Summoning.

After the submission, the Supervisory Council will make a summons, in accordance with Article 22, namely: ${ }^{15}$

a. The Chairman of the Examining Council shall summon the complainant and the reported party.

b. Summons are made by letter by the secretary at the latest 5 (five) working days before the trial.

c. In urgent circumstances, the summons as referred to in paragraph (2) may be made by facsimile followed by a summons.

\footnotetext{
${ }^{13}$ Mohamat Riza Kuswanto, Urgensi Penyimpanan Protokol Notaris Dalam Bentuk Elektronik dan Kepastian Hukumnya Di Indonesia, Jurnal Repertorium, Volume IV Nomor 2 July-December 2017, p. 64.

${ }^{14}$ Article 21 Regulation of the Minister of Law and Human Rights of the Republic of Indonesia Number: M.02.PR.08.10 of 2004 concerning Procedures for Appointment of Members, Dismissal of Members, Organizational Structure, Work Procedures, and Procedures for Examination of the Notary Supervisory Board

${ }^{15}$ Article 22 Regulation of the Minister of Law and Human Rights of the Republic of Indonesia Number: M.02.PR.08.10 of 2004 concerning Procedures for Appointment of Members, Dismissal of Members, Organizational Structure, Work Procedures, and Procedures for Examination of the Notary Supervisory Board
} 
d. In the event that the reported party is legally and properly summoned, but is not present, a second summons shall be made.

e. In the event that the reported party is legally and properly summoned for the second time but is still not present, the examination is carried out and the decision is pronounced without the presence of the reported party.

f. In the event that the reporting party is legally summoned and should not be present, a second summons shall be made, and if the complainant is still absent, the Examining Council declares the report void and cannot be submitted again.

3. Examination by Regional Supervisory Council

The Pemalang Regency Regional Supervisory Council will conduct an examination of the Notary in accordance with Article 23 and Article 24, namely: ${ }^{16}$

a. Examination by the Regional Examination Board is closed to the public.

b. The inspection begins within a period of no later than 7 (seven) calendar days after the report is received.

c. The Regional Examination Board must have completed the examination and submitted the results of the examination within a period of no later than 30 (thirty) calendar days as of the receipt of the report. The results of the examination as referred to in paragraph (3) shall be stated in the minutes of the examination signed by the chairman and secretary.

d. The cover letter for sending the inspection report sent to the Regional Supervisory Council is copied to the reporter, the reported party, the Central Supervisory Council, and the Regional Board of the Indonesian Notary Association.

4. Session Implementation

The Regional Supervisory Council convenes a session to examine and make decisions on public reports. At the appointed session, the reporter and the reported party are present, then the Regional Examiner Council conducts an examination by reading out the report and hearing the statements of the complainant. In the examination as referred to in paragraph (1), the reported party is given sufficient opportunity to submit a response. The complainant and the reported party can submit evidence to support the arguments put forward ${ }^{17}$. The report is examined by the Regional Examining

\footnotetext{
${ }^{16}$ Article 23 and 24 of the Regulation of the Minister of Law and Human Rights of the Republic of Indonesia Number: M.02.PR.08.10 of 2004 concerning Procedures for Appointment of Members, Dismissal of Members, Organizational Structure, Work Procedures, and Procedures for Examination of the Notary Supervisory Board

${ }^{17}$ Ong Argo Victoria, Ade Riusma Ariyana, Devina Arifani. (2020). Code of Ethics and Position of Notary in Indonesia. Sultan Agung Notary Law Review 2 (4), 397-407, http://lppmunissula.com/jurnal.unissula.ac.id/index.php/SANLaR/article/view/13536
} 
Council within a period of no later than 30 (thirty) calendar days as of the receipt of the report. The Regional Supervisory Council can only impose sanctions in the form of an oral or written warning. If the Regional Supervisory Council is Incract, then there can be no appeal. The Regional Supervisory Council may propose the imposition of sanctions against the Notary Public to the Central Supervisory Council in the form of temporary dismissal from 3 (three) months to 6 (six) months and dishonorable dismissal. After the report is forwarded to the Central Supervisor, the Central Supervisor proposes to impose sanctions in the form of dishonorable dismissal to the minister. Disrespectful dismissal is the toughest sanction imposed on a notary who violates the code of ethics and the Law on Notary Positions.

If a Notary who supervised if you continue to violate, then action will be taken. For this reason, the Notary concerned is subject to sanctions in accordance with applicable regulations by looking at the violations he has committed chapter 16 UUJN determines the obligations that must be carried out by a Notary in carrying out his position, namely:

1. Act honestly, thoroughly, independently, impartially, and protect the interests of the parties involved in legal actions.

2. Make a deed in the form of minutes of deed and save it as part of the Notary protocol.

3. Issue grosse deed, copy of deed, or deed quote based on the minutes of the deed.

4. Provide services in accordance with the provisions of the Notary Position Act, unless there is a reason to refuse it.

5. Keep everything about the deed he made and all information obtained for the making of the deed in accordance with the oath/promise of office, unless the law provides otherwise.

The Notary Position Act provides sanctions for Notaries who violate the provisions of Article 16 paragraph (1) letter b, as regulated in Article 85, the sanctions are in the form of:

1. Verbal reprimand

2. Written warning

3. Temporary stop

4. Respectful stop

5. Disrespectful dismissal

Yaya Kareng, Ong Argo Victoria, R. Juli Moertiyono. (2019). How Notary's Service in Thailand. Sultan Agung Notary Law Review, 1 (1), 46-56, http://jurnal.unissula.ac.id/index.php/SANLaR/article/view/4435 
In carrying out its practice, the notary is supervised by the Supervisory Board and the Honorary Council, because this supervision is very necessary so that the notary does not neglect his nobility and dignity, violates general regulations or other mistakes in carrying out his position as a notary. The Supervisory Board has the right to supervise the implementation of the code of ethics. Therefore, it is necessary to supervise the notary in carrying out his duties and positions. Efforts to supervise and foster in the implementation of the code of ethics enforcement carried out by the Notary Honorary Council have several authorities, one of which is to provide guidance, reform members, examine and make decisions on alleged violations of the code of ethics. Because the role of a notary in society is needed. So, ${ }^{18}$

\subsection{Obstacles and Solutions in Enforcing Law Against Notaries Who Do Negligence Against Minuta Deed Storage in Pemalang Regency}

There are obstacles in law enforcement against a notary who is negligent in keeping the minutes of deed based on Act No. 2 of 2014 concerning the position of a notary, namely as follows:

1. The notary Regional Supervisory Council does not have the authority to make decisions on public reports, so the community must wait a longer time to seek justice for their reports;

2. There is a very short time limit from the receipt of the report to the completion of the examination with members of the notary supervisory board consisting of 3 (three) elements, namely:

a. government;

b. Notary Organization;

c. Expert or Academic;

The Supervisory Council as intended consists of 9 (nine) people consisting of:

a. 1 (one) chairman concurrently member;

b. $\quad 2$ (two) representatives concurrently members; and

c. 6 (six) members

3. Lack of vision to carry out the supervisory function to the Notary and the absence of a good program to carry out the supervisory function.

4. Less widespread public knowledge about the procedure in reporting losses suffered for alleged violations committed by a notary.

The solutions that can be provided by the Regional Supervisory Council are:

a. Because the Regional Supervisory Council does not have the authority to ${ }^{18}$ Tri Ulfi, Anis Mashdurohatun, Urgensi Dewan Kehormatan Notaris Dalam Penegakan Kode Etik
Notaris Di Kabupaten Pati, Jurnal Akta, Vol 5 No 1 March 2018, Unissula, Semarang 
issue a report decision, the Regional Supervisory Council is required to immediately make an official report and immediately send it to the Regional Supervisory Council so that it can be processed immediately.

b. Make and immediately arrange a schedule for 3 (three) elements of the Supervisory Council members who have free time and when there is time so that they can be immediately scheduled to carry out inspections.

c. So that the members of the Supervisory Board have more time to be able to plan the current vision and for the future to carry out supervisory duties and improve performance.

d. Provide socialization and appeal to the community from the Regional Supervisory Council, Regional Supervisory Council, Ministry of Law and Human Rights and legal counseling

With a lot legal events that occur, thus encouraging and demanding the public of the importance of the strength of proof of a deed, causing the role of a notary as a public official to always follow legal developments to people who need and maintain the deeds he made to always be able to provide legal certainty. Law enforcement is an effort made to make the law, both in a narrow formal sense and in a broad material sense, as a behavioral guide in every legal act, both by the legal subjects concerned and by law enforcement officials who are officially given the task and authority by law. Laws to ensure the functioning of legal norms that apply in the life of society and the state. Law enforcement basically contains the supremacy of substantial values.

\section{Closing}

Based on the description above, the conclusions in this study are: 1) Law enforcement against notaries who neglect to keep the minutes of deed in Pemalang Regency is carried out based on the Regulation of the Minister of Law and Human Rights of the Republic of Indonesia Number: M.02.PR.08.10 of 2004 concerning Procedures for Appointment of Members, Dismissal of Members, Organizational Structure, Administration Work, and Procedures for Examination of the Notary Supervisory Board. The reporting mechanism or procedure is the submission of the report, summons and examination by the MPD, as well as the conduct of the trial by the MPW. Sanctions against Notaries who are proven to have violated the provisions of Article 16 paragraph (1) letter $b$, as stipulated in Article 85, the sanctions are in the form of verbal warnings, written warnings, temporary dismissal, 2) Obstacles in enforcing the law against a notary who neglects to keep the minutes of deed in Pemalang Regency, namely 1). The notary Regional Supervisory Council does not have the authority to make decisions on public reports, so the community must wait a longer time to seek justice for their reports. 2) There is a very short time limit from the receipt of the report to the completion of the examination with members of the notary supervisory board. 3) Lack of vision to carry out the supervisory function to the 
Notary and the absence of a good program to carry out the supervisory function. 4) Less widespread public knowledge about the procedure in reporting losses suffered for alleged violations committed by a notary. Possible solutions are: 1) The Regional Supervisory Council is required to make an official report as soon as possible and immediately send it to the Regional Supervisory Council so that it can be processed immediately. 2) Make and immediately arrange a schedule for 3 (three) elements of the Supervisory Council members who have free time and when there is time so that they can be immediately scheduled to carry out inspections. 3) So that the members of the Supervisory Board have more time to be able to plan the current vision and for the future to carry out supervisory duties and improve performance. 4) Provide socialization and appeal to the public from the Regional Supervisory Council, Regional Supervisory Council, Ministry of Law and Human Rights and legal counseling.

\section{References}

Journals:

[1] A Chuasanga, Ong Argo Victoria. (2019). Legal Principles Under Criminal Law in Indonesia and Thailand, Jurnal Daulat Hukum, Vol 2, No 1 (2019) http://jurnal.unissula.ac.id/index.php/RH/article/view/4218

[2] Astari Pryandini, "kedudukan Hukum Salinan Akta Notaris Dalam Hal Terjadinya Musnahnya Akta", Justitia Jurnal Hukum, Vol. 2 No.1, April 2018

[3] Cut Era Fitriyanik, The Responsibility of Notary Towards Keeping The Minutes of Legal Documentary as a Part of Notary Protocol, Kanun Jurnal IImu Hukum, Nomor 58 Tahun XIV December, p. 395

[4] Deen, Thaufiq., Ong Argo Victoria \& Sumain. (2018). Public Notary Services In Malaysia. JURNAL AKTA: Vol. 5, No. 4, 1017-1026. Retrieved from http://jurnal.unissula.ac.id/index.php/akta/article/view/4135

[5] Mohamat Riza Kuswanto, Urgensi Penyimpanan Protokol Notaris Dalam Bentuk Elektronik \& Kepastian Hukumnya Di Indonesia, Jurnal Repertorium, Volume IV Nomor 2 July-December 2017, p. 64.

[6] Ong Argo Victoria, Ade Riusma Ariyana, Devina Arifani. (2020). Code of Ethics and Position of Notary in Indonesia. Sultan Agung Notary Law $\begin{array}{llll}\text { Review } & 2 & (4), \quad \text { 397-407, } \quad \text { http://lppm- }\end{array}$ unissula.com/jurnal.unissula.ac.id/index.php/SANLaR/article/view/13536 
[7] Sri yuniati \& Sri Endah Wahyuningsih, Mekanisme Pemberian SanksiTerhadap Notaris Yang Melakukan Pelanggaran Kode Etik Jabatan Notaris, jurnal akta, Vol. 4, No.4, 4 December 2017

[8] Yaya Kareng, Ong Argo Victoria, R. Juli Moertiyono. (2019). How Notary's Service in Thailand. Sultan Agung Notary Law Review, 1 (1), 46-56, http://jurnal.unissula.ac.id/index.php/SANLaR/article/view/4435

Books:

[1] Afipuddin, Implikasi Hukum Protokol Notaris Sebagai Arsip Negara, Tesis Program Studi Magister Kenotariatan, Universitas Narotama

[2] Ahmad Ali, 2008, Menguak Tabir Hukum, Ghalia Indonesia, Jakarta

[3] C.S.T Kansil, et. al., 2003, Pokok-Pokok Etika Profesi Hukum, Pradnya Paramita, Jakarta

[4] Habib Adjie, 2009, Sanksi Perdata dan Administratif Terhadap Notaris Sebagai Pejabat Publik, Refika Aditama, Bandung

[5] Herlien Budiono, 2013, Dasar Teknik Pembuatan Akta Notaris, Citra Adiyta Bakti, Bandung

[6] Indra Iswara, 2020, Profesi Notaris dan PPAT ditinjau dari Perspektif Hukum Islam, Maktabah Muslim Sunni, Kediri

[7] Karya Gemilang, 2009, Himpunan Peraturan Perundang-Undangan Jabatan Notaris dan PPAT, Indonesia Legal Center Publising, Jakarta

[8] Karya Gemilang, 2009, Himpunan Peraturan Perundang-Undangan Jabatan Notaris dan PPAT, Indonesia Legal Center Publising, Jakarta

[9] Maya Malinda Panjaitan, Analisis Yuridis Tanggung Jawab Notaris Dalam Membuat dan Menyimpan Minuta Akta, Premise Law Journal, Volume XIV of 2017

[10] Paulus Hadisoeprapto,dkk, 2009, Pedoman Penulisan Usulan Penelitian dan Tesis, UNDIP,Semarang

[11] Pengurus Pusat Ikatan Notaris Indonesia, Editor Anke Dwi Saputra, 2008, Jati Diri Notaris Indonesia Dulu, Sekarang Dan Dimasa Yang Akan Datang, Gramedia, Jakarta 
[12] Pengurus Pusat Ikatan Notaris Indonesia, Editor Anke Dwi Saputra, 2008, Jati Diri Notaris Indonesia Dulu, Sekarang Dan Dimasa Yang Akan Datang, Gramedia, Jakarta

[13] R. SoegondoNotodisoerjo, 1993, Hukum Notariat di Indonesia, RajaGrafindo Persada, Jakarta

[14] Sjaifurrachman, 2011, Aspek Pertanggungjawaban Notaris dalam Pembuatan Akta, Mandar Maju, Bandung.

Regulation:

[1] Act No. 02 of 2014 concerning the Law on Notary Positions.

[2] Constitution 1945

[3] Regulation of the Minister of Law and Human Rights of the Republic of Indonesia Number: M.02.PR.08.10 of 2004 concerning Procedures for Appointment of Members, Dismissal of Members, Organizational Structure, Work Procedures, and Procedures for Examination of the Notary Supervisory Board 